\title{
ASPECTOS DO FENÔMENO DO CANGAÇO NO NORDESTE BRASILEIRO (V).
}

(Conclusão) .

\author{
MARIA CHRISTINA RUSSI DA MATTA MACHADO \\ Licenciada em História pela Pontifícia Universidade \\ Católica de São Paulo.
}

\section{FIM DO CANGAÇO.}

A decadência do cangaço é fruto de mudanças que se operaram no plano nacional e regional.

Em termos globais, é fundamental levar em consideração as mudanças de ordem política, econômica e social.

Com a revolução de 1930, a política brasileira passou por transformações mais aparentes do que reais, em termos de alterações econômicas-sociais (subida e melhoria das classes mais pobres em detrimento dos ricos, etc. ).

Ainda que as oligarquias, aparentemente, se mostrassem solidárias com o Poder Central, na verdade a intransigência de Washington Luiz, no tocante à política cambial e cafeeira, dava causa à desagregação da homogeneidade das classes conservadoras, em torno da Presidência da República. Não obstante, quando se apresentou o problema sucessório, as mais expressivas unidades representantes do poder Econômico se manifestaram através de documentos públicos, solidárias com o candidato do Catete. Não apenas as associações rurais, mas tambem os grêmios, as entidades etc., que aglutinavam as novas forças produtivas emergentes na esfera industrial (Confederação Nacional da Indústria, etc.), formalmente, acolheram o nome indicado por Washington Luiz.

À primeira vista, parecer-nos-á chocante o fato das associações de classe (associações representativas de classes produtoras) no plano da lavoura, do comércio ou da indústria, através de manifestos, desde logo, externarem solidariedade ao governo de Washington Luiz e ao seu candidato paulista Júlio Prestes, representante da oligarquia de 
São Paulo. Contudo, compreender-se-á essa atitude se examinarmos a tradição política da República, cujas origens mostram a constante solidariedade ao poder central, expressão dos interesses globais de uma estrutura agrária politicamente representada pelos Partidos Republicanos, traduzindo os interesses oligárquicos regionais. Tenha-se em conta que o processo de diferenciação econômica, mesmo nos albores da revolução de 30 , não lograra definir-se em vertentes autônomos, isto é, agrarismo e industrialização. Esta última, nada representava em nosso balanço de pagamentos - então altamente deficitário - que, sobretudo no café, encontrava minguados recursos para atenuar esse desequilíbrio (1).

(1). - A chamada revolução de 30 se insere num processo "revolucionário" que atingiu vários países da América Latina, dado o carater dependente da economia de toda essa parte do Hemisfério Ocidental, composto de países exportadores de produtos agro-pastoris, matérias-primas, matérias extrativas. Contudo, é preciso acentuar que os anseios de renovação da estrutura econômico social desses países retardatários, entre os quais situava-se o Brasil, volta e meio emergiam através de movimento de contestação armada. Especificamente no Brasil, a revolução de 30 , precedida de uma série de rebeliões, traduz uma das chapas mais expressivas, pois se situa num dos pontos culminantes de um processo iniciado em 1922, e que engendra o que a história viria a chamar de Tenentismo.

Embora a liderança, de fato, do movimento, fosse de ordem militar, a contribuição civil ainda que caudatária se fez tambem presente.

O fato da liderança ser militar explica-se por vários motivos:

$\left.1^{\circ}\right)$. - As forças armadas eram um estamento que, apesar de talado por contradições internas, representava uma unidade não existente entre as chamadas classes conservadoras distribuidas ao longo do território, pelas várias oligarquias.

29). - O Brasil mal entrava pela senda da urbanização, o que implica o predomínio das áreas rurais sobre as cidades:

$\left.3^{\circ}\right)$. - A industrialização, ainda incipiente, limitando-se praticamente ao ramo textil e à alimentação, não havia gerado, na medida reclamada, urr, proletariado capaz de impor-se como força social, ainda que se considere o fato de o decênio do século ter assistido, no seu término, a um dos acontecimentos mais significativos da história contemporânea que foi a Revolução Russa. A todo passo, se vem próceres das classes conservadoras evocando o "espectro do comunismo", como ameaça presente, com o propósito de justifcar a necessidade da pacificação entre suas várias facções oligárquicas, em choque com interesses regionais.

$O$ governo ainda que propendesse para o agrarismo, contava com as classes produtoras em seu conjunto. Isso ocorria porque estas viam nas manifestações dos anseios populares pela liberdade, expressos pelas frequentes rebeliōes-ameaças à estrutura econômico-sociais vigentes. A tradição de "vitória" do grupo no poder era consiaerada, tambem, um fato inelutavel.

Dai toda a fase que precede a chamada Revolução de 30 ser marcada por documentos públicos das entidades da classe produtora, contendo declarações de solidariedade ao situacionismo.

O presidente era, de fato, o coordenador das oligarquias, através dos partidos políticos e chefes regionais. 
Quando a crise éconômica internacional de 1929 começou a ganhar corpo, as medidas de Washington Luiz para reduzir suas consequências, no Brasil, com a modificação da política cafeeira, já não poderiam contorna-la nas dimensões necessárias, em face da intransigência anterior.

O fluxo emissionário, para sustentação dos preços internos do café, teve pronta consequência sobre o nivel de vida das parcelas dos setores desafortunados da população brasileira, criando um mal-estar generalizado, capaz de robustecer a onda de descontentamento com o regime, já acentuada, no início do decênio dos 20 .

As várias tentativas insurrecionais, que ganham corpo partícularmente em 24, fixam sua linha ascendente, criando o que se chama de Tenentismo, sem contudo transpor os limites dos quadros políticos institucionais. O descontentamento popular é sentido pelas várias facções oposicionistas, que se esboçam mais em termos políticos que sociais, quando se apresenta o problema sucessório, ainda que Getúlio Vargas, candidato da Aliança Liberal, veja, sobretudo na solução da crise cafeeira, a terapêutica imediata para a cura dos graves males que afetaram a nação. O próprio tenentismo, que se agrupa em tôrno do candidato da Aliança Liberal, afora pouquíssimas exceções, não tem à sua frente outras perspectivas senão as de natureza política.

Sob a bandeira desfraldada pelo gaucho Assis Brasil - Representação e Justiça - estava a panacéia para a terapêutica dos males que afligiam o país.

Imposta pelas armas a vitória de Getúlio Vargas, em outubro de 1930 , nenhuma medida radical para uma reestruturação da base econômico-social do país foi tomada. As oligarquias regionais, imperantes até 1930, quando muito, sofreram arranhões de superfície, mas de fato, não viram seu poder econômico reduzido, dado que era ainda o café, e outros produtos agro-pastoris e extrativos, que determina-

Getúlio Vargas, embora cercado pelo calor do entusiasmo popular, ao desencadear a revolução de 30 , teve como esteio não os grupos oligárquicos, que compunham as chamadas classes conservadoras, mas o tenentismo, que, embora ideologicamente contraditório e mesmo marcado em largos setores por um cunho autoritário, oferecia novas perspectivas para a saida da crise econômica que abalava o país.

Sob a pressão do tenentismo, os próceres civis da revolução de 30 são obrigados, na primeira fase do movimento a aceitar algumas medidas de natureza social e econômica (Código de Minas, Ministério do Trabalho etc.) mas que não feriram, sequer superficialmente, a estrutura econômica do Brasil, assentada sobre a grande propriedade rural. 'A inspiração, que traduzia os anseios do povo, era configurada pela bandeira do tenentismo. 
vam $70 \%$ de nossa exportação. Todas as medidas empreendidas pelo governo provisório de Getúlio Vargas, todas as promessas imbuidas de idealismo das alas mais progressistas do tenentismo, não passaram de vãos acenos que se chocavam com a realidade irredutivel, de uma estrutura agrária, determinante da política econômico-financeira.

A crise cafeeira promoveu o deslocamento de capitais excedentes para a área industrial, ainda que não chegando a modificar-lhe a fisionomia preponderante, onde pesavam, como índices básicos, a indústria textil e a da alimentação.

A Revolução de 30 , tendo como motivo tambem esse fator (crise cafeeira), acelerou o processo de urbanização, impondo ao chamado Governo Provisório, entre outras medidas, a criação do Ministério do Trabalho, que constituiu para aqueles tempos, uma singularidade.

A crise cafeeira, consequente a uma crise internacional, dá origem à transferência de capitais para a área industrial, estimulando-lhe o crescimento, ainda que em medida pouco relevante.

A chamada Intentona de 1935, promovida pela Aliança Nacional Libertadora e que agrupava um suposto tenentismo de esquerda e a pequena burguesia radical, é outra etapa - ainda que com veleidades esquerdistas - no itinerário que levaria Getúlio Vargas ao golpe de Estado de 1937, instaurando o Estado Novo.

O Estado Novo, a um só tempo, pretende destruir os grupos oligárquicos resistentes e o radicalismo esquerdizante, de que fez parte o próprio partido Comunista do Brasil.

O golpe de Estado, de 1937, arma Getúlio e seus seguidores dos instrumentos institucionais de carater autoritário, para uma reformulação política estrutural do Estado Brasileiro. A constituição outorgada, que se baseia em prinćípios fascistas, já vigentes em alguns Estados europeus (Itália, Alemanha, Polônia, Portugal), suprimiu as liberdades democráticas e impôs ao sindicalismo um sistema corporativo, conferindo ao chefe de Estado poderes ditatoriais. Por meio desses institutos, Getúlio designa representantes seus, interventores-instrumentos, para execução de reformas que dotam o Estado Brasileiro de um arcabouço centralizador.

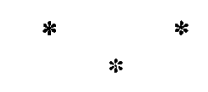

Considerações finais.

$\mathrm{Na}$ verdade, erigido ao poder, o grupamento, que se chamou Aliança Liberal, circunşcreveu suas reformas aos limites de natureza política, não atacando nenhum dos problemas que poderiam, efetiva- 
mente, constituir alicerce de um Estado representativo de forças sociais em ascenção, capaz de propiciar condições para um real desenvolvimento das forças produtivas nacionais. Mesmo dentro dessas limitações, as oligarquias sobreviventes, encabeçadas pela mais poderosa delas, a de São Paulo, tentaram jugular ameaças potenciais que as camadas menos afortunadas e a classe média abrigvam. A Revolução de 32 pode constituir o mrco mais significativo, no sentido da contenção de um processo desencadeado, ainda que no plano puramente das promessas.

Reuniu-se a Assembléia Nacional constituinte em 15 de novembro de 1933, mas não resolveu nenhuma dąs contradições, tanto assim que foi desembocar no golpe de estado de 37.

O problema da terra não foi objeto de preocupação. Fez-se a Constituição, com reformas políticas superficiais (voto secreto etc.), mas não foram enfrentados problemas básicos.

É importante analisarmos até que ponto as modificações políticas, ocorridas no âmbito geral, vão influir no plano regional.

A Revolução de 1930 provocou desajustes nas fazendas dos senhores rurais, base das oligarquias regionais. As perseguições políticas continuaram, e os donos das terras sentiram-se inseguros e desanimados com o crack de 29 ; os produtos nacionais tiveram seus preços reduzidos no mercado internacional.

"Não se julgue, por isso, que houve uma ruptura completa e definitiva entre a burguesia e o latifúndio. A velha aliança anteriormente existente fazia-se agora sob uma nova fórmula, numa inversão de papéis: que estava por baixo passa para cima. $O$ conluio continua" (2).

Até 1930 , as oligarquias dominavam e o Estado aceitava, na medida em que interessava a ele, os votos dos municípios.

Em 1930, ainda com Washington Luiz na presidência, os coronéis estavam do seu lado.

Os revolucionários da Aliança Liberal tiveram a maioria dos chefes contra eles.

Quando irrompe o movimento armado no Sul, um jornal da Bahia comentou:

(2). - Facó (Rui), Cangaceiros e Fanáticos, pág. 18. 
“... Oes coroneis Franklin Albuquerque e Hcrácio de Matos, que há anos com tanta eficiência acossaram na zona sertaneja as tropas rebeldes de Luiz Carlos Prestes, já organizaram, cada qual, três batalhôes com efetivos de 500 homens cada. Do coronel Franklin, o presidente da República recebeu um telegrama nestes termos: "Obedecendo à orientação do senador Pedro Lago, deputado Simões Filho e do dr. Geraldo Rocha, organizei um batalhão para a defesa da legalidade e do respeito aos poderes constituidos. Neste posto V. Excia. me encontrará como de costume" (3).

Com a ditadura de Getúlio, configurada no Estado Novo, não haveria mais necessidades dos coroneis darem votos ao Estado.

Com a centralização do poder, em mãos do ditador, com a supressão das Assembléias Legislativas, com a supressão de toda representatividade direta do povo (eleições), os famigerados "currais", que eram nutridos pelo coronelismo, perderam sua razão de existência, levando, consequentemente, os chefes políticos sertanejos, a uma posição de subalternidade, quando não do desaparecimento puro e simples.

Além disso, o Governo Federal, sustentado pelas Forças Arm?:das, concentra em suas mãos as decisões e o comando dos Estados, não dá poder aos senhores rurais; ao contrário, penetra em suas fazendas afrontando-os; não precisa mais deles.

"As armas não tinham sido depostas, e, por todo o Nordeste os ânimos ainda acendidos, eram desarmados os coroneis. A medida generalizou-se. Na Bahia, o próprio chefe de polícia comanda a ação a diferentes municípios do interior, detem coroneis, submete-os a interrogatórios, vareja-lhes as fazendas, arrecada-lhes as armas" (4).

As oligarquias regionais, que em outubro de 1930 já haviam recebido alguns golpes, a partir de 1937 são feridas mais profundamente. E verdade que, amparadas ainda nas velhas estruturas praticamente incôlumes, sobretudo no tocante à propriedade da terra, não desaparecem, mas em larga parte se renovam através de outros representantes.

(3). - Facó (Rui), Obr. cit., pág. 195 - (jornal A Tarde da Bahia de 14-10-1930).

(4). - Facó (Rui), Obr. cit., pág. 194. 
No domínio politico, o Estado Novo, se não elimina, reduz consideravelmente os meios de que dispunham as velhas oligarquias no tocante às forças militares locais.

As polícias locais, a mando dos oligarcas, bandos armados "provisórios" (Rio Grande do Sul), - passam ao controle do Exército e este agora passa a mandar em toda extensão territorial do país.

Praticamente as forças armadas, polícia, milícia etc., ante às ordens das oligarquias regionais, ficam subordinadas ao poder central. O "ideal" centralizador do Estado Novo se expressa na brusca diminuição, digo, na busca da eliminação das veleidades da autonomiä dos grupos oligárquicos, que dispunham até mesmo de forças militares regionais, O federalismo, esteio das Constituições anteriores e instrumento nas mãos das oligarquias, sofre significativas limitações. Com as modificações ocorridas em termos nacionais e regionais, provocando abalo no comportamento do coronel; com as transformações que se operam em termos de política, no campo e, ainda, a maior influência exercida pelo Poder Central no sertão, o cangaço teve de sofrer, forçosamente, um retrocesso que o levou mais tarde ao seu término.

\footnotetext{
"Aqui jais Virgulino Ferreira da Silva Lampião o urtimo cangaceiro".

"Uma legenda de morte que o vento varreu e espalhou no vazio da caatinga, no nada da vida, na contingência do tempo e na passagem da história por uma das pedreiras das margens do Velho São Francisco" (5).
}

Uma legenda escrita por um soldado com a ponta do dedo sobre a terra que cobriu os restos mortais, já quase apodrecidos, de Lampião, lá mesmo na grota dos Angicos onde ele foi morto.

$\mathrm{Na}$ simplicidade do gesto e numa frase que representou a homenagem do soldado sertanejo ao Rei do Cangaço, a expressão, "urtimo cangaceiro", era manifestação de uma previsão que iria se tornar realidade.

Morto Lampião, morria o cangaço.

A morte de Lampião foi a causa imediata do fim do cangaço. Exisitiram contudo outras causas, mediatas ou remotas. Lourenço Filho, em seu livro O Juazeiro do Padre Cícero, de 1926, fala dos remédios para terminar o cangaço e cita:

(5). - Goes (Joaquim); Lampião o último cangaceiro, pág. 242. 
"Estão, no entanto, aos olhos de todos, os remédios. Eles se resumem, numa palavra, em maior liberdade política aos escravisados dos Estados do Norte, em distribuição de justiça e educação, ao povo dos Sertões" (6). rista?

Que motivos teriam determinado o fim do movimento cangacei-

Vários fatores devem ter contribuido para a extinção do fenômeno.

Seria conveniente analisarmos, agora, alguns deles que ajudaram a encerrar o movimento. Na sua fase final, com as mudanças já se operando, o cangaço declina, a partir de 1930. E provavel que as principais expressões desse declínio tenha sido:

\section{I. - Entrada do elemento feminino.}

Muito embora a entrada da mulher no cangaço tenha contribuido para provocar maior aproximação entre o cangaceiro e a sociedade sertaneja, a verdade é que tal mudança foi a expressão de um certo enfraquecimento nos propósitos originários do homem revoltado.

Antes de 1930, Lampião negou-se, sistematicamente, a aceitar participação do elemento feminino naquela vida nômade.

"Quem veve nesta vida num pode pensá in casa". "Nem ter Muié" (7).

Lampião pensava assim em Pernambuco, mas já modificava sua opinião na Bahia e, não só se deixou acompanhar por Maria Bonita como permitiu que seus "cabras" procurassem companheiras para segui-los no cangaço. Incorporar a mulher ao bando revelava a visão diferente contra a injustiça. A revolução de 30 deu-lhe a confiança para ingressar na sociedade, certo de que não haveria mais injustiças.

Com o enfraquecimento das oligarquias, é provavel que Lampião intuisse e acreditasse numa forma mais calma e mais segura de vida depois da revolução de 1930 .

Isso parece confirmar-se no fato de haver Lampião, depois de ter Maria de Déia como sua companheira, procurado por-se ao abri-

(6). - Lourenço (Filho), O Juazeiro de Padre Cícero, pág. 178.

(7). - Depoimento de "Zé Sereno", remanescente do cangaço. 
go das perseguições, permanecendo onze meses em inatividade, na fazenda Capim, no município de Porto da Folha, Estado de Sergipe.

Tendo feito uma acordo com um sargento, que estava com um destacamento em uma cidade próxima, a-fim-de- não lhe dar combate, Lampião por sua vez ficaria tranquilo em seu coito (8). Esta paz selada pelo cangaceiro, mostra seu desinteresse em ataques, disputas etc.

"Possuir uma amante permanente, foi o primeiro erro de Virgulino Ferreira, ato que deu lugar a que os seus subchefes quisessem tambem gozar do mesmo direito".

"Daí por diante abriram-se as fileiras da família maldita do crime para o ingresso e permanência de mulheres de todo quilate". "Só de Sergipe, da Zona de Pôço Redondo, contam-se Rosinha, Aldina, Enedina, Cira e Aurea, estas duas últimas, irmãs".

"Por fim, a terrivel e diabólica pernambucana Dadá, mulher de Corisco" (9).

Esse comportamento demonstra que o cangaceiro já não suportava levar essa vida agitada pelas lutas constantes, sem a companhia de uma mulher que lhe proporcionasse uma existência a dois. E, no momento em que a mulher é aceita no cangaço, esse homem passa a acautelar-se um pouco mais, não se atirando, afoitamente, às lutas, como ocorreria nos anos que antecederam sua chegada à Bahia. Agora ele necessitava de se resguardar e dedicar-se mais a uma companheira, que dividia com ele as dificuldades daqueles passos arriscados. Os cangaceiros começaram a procurar frequentemente os "coitos", e suas atividades visavam, mais objetivimante, à subsistência .

"Não há pois como negar que a permanência da amante de Virgulino Ferreira nas hostes do banditismo modificou, de ieve, a estrutura da organização sinistra".

"Lampião tornou-se mais esquivo, menos audaz nas arremetidas, amolentando assim a rigidez férrea que sustentava o segredo da invencibilidade daquela estranha sociedade.

"Maria Bonita escondia-o para sua paixão, prendeu-o às suas carícias, distanciando-o do perigo de perde-lo" (10).

Segundo nosso entender, não se tratava disso; na verdade a integração das mulheres no bando traduzia um novo estado de espírito.

(8). - Confronto com a obra de Joaquim Goes.

(9). - Goes (Joaquim), Lampião, o último dos cangaceiros, pág. 219.

(10). - Goes (Joaquim), Obr.. Cit., pág. 223. 
As condições histórico-sociais eram diferentes. Com a revolução, os cangaceiros acreditavam que iam ter paz, tranquilidade; com o coronelismo desmantelado, não havia mais necessidade daquela vida.

Estavam cansados, queriam mudar, queriam novamente fazer parte da comunidade.

\section{II. - A motivação ao cangaço.}

A entrada de Lampião no cangaço foi impulsionada por motivo muito forte. Mataram seus pais e ele precisava vinga-los. $\mathrm{O}$ mesmo ocorreu, anteriormente, com Antônio Silvino, cujo pai foi assassinado numa emboscada. Assim, vamos encontrar uma série de outros elementos que buscaram o cangaço como forma mais objetiva de justiça contra morte de familiares, roubo de terras e violências sexuais praticadas contra parentes.

Com o crescimento da fama de Lampião e com o recrudescimento do cangaço, surgiram as medidas governamentais para combate-lo. As volantes, soldados contratados pelos representantes dos Poderes Públicos, agiam no sertão. Passaram a perseguir os cangaceiros, na esperança de poder extinguir o fenômeno.

"E como, na concepção estreita dos comandantes das volantes, cada solitário habitante da zona infestada pelo cangaço podia ser um coiteiro, as torturas, as surras de "pinhão", desabavam sobre todos, inocentes e culpados".

"Como resultado dessas medidas extremas nasceu e cresceu no peito daquela gente um ódio de morte aos representantes da ordem pública nas caatingas".

"Entre eles criou-se um aliança, um contrato de solidariedade coletiva: vingar-se das tropas do governo. E se vingaram aliando-se aos bandidos, muitos por dinheiro, outros pelo medo de morrer se os delatassem e quase todos pela desforra das surras e dos espancamentos que os homens da lei, frustrados na sua missão, thes aplicavam ferozmente".

"Os infelizes que a nossa volante interrogava naquele momento, foram chicoteados para dizer o que sabiam e o que ignoravam".

"A verdade é que, nada de positivo ou de proveitoso nos veio das confissóes extorquidas pelo argumento físico das cacetadas" (11).

(11). - Goes (Joaquim), Op. Cit., pág. 10! . 
A participação das volantes, na luta pelo extermínio dos cangaceiros, provocou, sem dúvida, situação das mais angustiantes para o sertanejo.

"Todos eram suspeitos e nenhum merecia confiança porque, comumente, entre eles estava um vigia, um delator, um informante, alugado ou não, para inteirar aos bandidos de todos os passos das forças que os perseguiam" (12).

O sertanejo, que já se espantava muitas vẹzes com a figura do cangaceiro, passou a viver entre dois fogos: o da volante, que espancava, para saber a pista dos revoltosos; o do cangaceiro que não perdoava os delatores.

Em função disso, passou a nascer um novo tipo de cangaceiro, que era o homem que fugia do massacre das volantes, ou que se revoltava contra elas, entrando no cangaço para vingar-se. Esse foi um novo tipo de cangaceiro incorporado, em grande escala, aos grupos que se espalhavam pelos sertões nordestinos. O cangaço crescia nesse outro tipo de revolta, mas o novo cangaceiro incorporado ao movimento não possuia as mesmas motivações que determinaram o aparecimento de "Lampião", Antônio Silvino, "Labareda", "Saracura" e outros.

Um outro fator, determinante do aparecimento de novos cangaceiros, foi a fama colhida por "Lampião" nos sertões. O povo, de um modo geral, via, no homem do cangaço, um forte que esbanjava dinheiro e que ditava ordens. Criou-se o fascínio, e essa era uma razão suficientemente forte para a entrada de novos elementos nesta vida.

"Lampeão tem muita idéia

Sua vida está segura,

Atirá nêle é bobage

A bala bate e não fura.

O rifle de Lampeão

$E$ na verdade um tesouro

O cano é todo de prata

E a coronha é de ouro.

Ninguém pega Lampião

Que êle tem muita mandinga

Se envulta em toda a parte

Quanto mais lá na' caatinga

(12). - Goes (Joaquim), Op. Cit:, pág. 101. 
Lampião é rapaz moço

Pode ter vinte e um ano

Ter cartucheira de prata

$\mathrm{E}$ um rifle americano.

Lampião é home rico

Tem dinheiro com fartura

No lugá onde passa

Dá esmola e faz figura.

A mulé de Lampião

E danada prá luxá

Prefume de toda casta

Tem dentro do seu borná.
A mulé de Lampião
É faceira e é bonita
Cada cacho de cabelo
Tem cinco lenço de fita.

A mulé de Lampião

Teve dois Lampiãozinho,

Sendo um macho e um feme

Todos dois engraçadinho.

Adeus, Adeus, minha mãe

Me dê a sua Bençãc,

Vou acertá minha vida

No grupo de Lampiãu.

O chapéu de Lampião

E bonito, é enfeitado

Tem prata de toda banda,

Tem ouro de todo lado.

No, logá por onde passa

$O$ bando de Virgolino

Sacristão lá na igreja

Vai logo batê no sino.

O rifle de Lampião

Dá cem tiro num minuto

Já tem feito muita gente

Lá no sertão botá luto. 
Lampião é mandingueiro Tem muita idéia guardada Atravessa o S. Francisco Sem canôa e sem jangada.

Lampião o S. Francisco

Atravessa aonde qué

A pinranha caio dente

Perde a fôrça o jacaré.

O rio de S. Francisco

No seu mais fundo lugá

Se abre em toda largura

Para Lampião passá".

Nos primeiros dez anos de cangaço, Lampião preocupava-se, sobremaneira, com os elementos que o procuravam então os aceitava se não houvesse um motivo muito forte. Com o crescimento do cangaço, entretanto, e com a subdivisão dos grupos, não the foi possivel fazer qualquer seleção. Podemos dizer que muitos cangaceiros atuaram naquelas regiões sem ter tido a oportunidade de conhecer Lampião. $O$ cangaço passou a ser um refúgio para os oprimidos pelas volantes, para os fora-da-lei, como tambem, para aqueles que sonhavam com a boa vida e a fartura (13).

Essas novas perspectivas disvirtuaram, certamente, o cangaço nos seus aspectos mais originais. Os novos elementos que se engajavam na vida do mato, nem sempre carregavam aquelas condições que levaram outros cangaceiros ao movimento.

Para reforçar tal observação, considere-se o episódio que ocorreu depois da morte de Lampião, quando o governo resolveu conceder anistia aos que continuavam na luta. Muitos deles se entregaram à polícia, vestiram-se de volantes e foram perseguir os companheiros mais velhos, que se recusaram a aceitar as condições de paz propostas pelo governo (14).

Lampião jamais aceitaria envergar a farda da volante, e se misturar aos "macacos" que ele sempre odiou.

\footnotetext{
(13). - Depoimento dos ex-cangaceiros - "Balão", "Pitombeira" e "Dadá".

(14). - Depoimento dos ex-cangaceiros - "Labareda" e "Saracura".
} 


\section{A Volante e a Metralhadora.}

Claro que existiram outras razões menos fortes, mas que ajudaram tambem o término do cangaço.

A criação das volantes, se de um lado provocou um clima de maior violência no sertão e o consequente surgimento de novos cangaceiros, de outro determinou menor sossego aos proprios cangaceiros.

A perseguição anteriormente era feita pela polícia, sem especificação de elementos talhados para aquela tarefa. Percebeu contudo o governo que, para lutar numa região de tão dificil acesso, somente outros sertanejos, acostumados ao rigor do clima e dos caminhos tortuosos, poderiam faze-lo. A polícia nunca teve rastejadores, mas a volante os possuia; a polícia nunca teve coragem de penetrar numa região como o Raso da Catarina, mas os elementos da volante chegavam a faze-lo; enfim, os homens das volantes eram, na realidade, cangaceiros vestidos com farda e tendo, ao seu lado, a lei.

Paralelamente, o governo conseguiu engajar, nas fileiras das volantes, alguns ex-coiteiros do cangaço, homens que estavam acostumados a lidar com os grupos de Lampião.

"Esses coiteiros foram ficando revoltados e foram pegando em armas e foram virando "macaco" e perseguindo com as fôrças, e isso veio sendo o fracasso dos grupos. Quer dizer que todos os coiteiros que conheciam todos os sistemas dos cangaceiros, como nós era, nossos pontos, tudo aquilo eles sabiam.

Quando foi no tempo que eles entravam nas volantes prá perseguir junto com as volantes já sabiam todo os sistema dos cangaceiros. Se num fôsse assim num acabava nunca, nem cum exército, nem cum esquadra de aviadores. Eles nunca davam fim nisso. Quem terminou o grupo e todo o fracasso dos cangaceiros foi os paisanos, os contratados que eram coiteiros, que se contratavam e botaram prá perseguir a gente, porque todos os costumes do cangaceiros eles conheciam. Foi quem acabou com o grupo foi isso, não foi a polícia não. Nem foi a aviação, nem foi o Exército. Não foi nada, porque eles não iam naqueles mundo que ia o cangaceiro. Naquelas montanhas, naquelas serras, passá sêde, no espinho. Eles num iam nisso não. Porque que ia mesmo nestas coisas era o contratado, que era o mesmo que cangaceiro" (15) . 1969.

(15). - Depoimento de Sérgia da Silva Chagas — vulgo "Dadá" em 
Os cangaceiros não procuraram equipar-se com melhor armamento. Eles conheciam a metralhadora, conforme afirma hoje José Ribeiro, vulgo "Zé Sereno", mas não gostavam de usa-la, porque seu peso representava um problema. Outros cangaceiros remanescentes garantem, contudo, que "Lampião" já havia feito uma "encomenda", e que os grupos iriam receber essa arma mais moderna. Tudo leva a crer, no entanto, que os fornecedores de armas não estavam em condições de atender a esse tipo de encomenda.

A metralhadora foi, em verdade, um peso favoravel aos homens da volante.

Eles a usavam em grande escala, notadamente nos tres anos que antecederam a morte de Lampião. E foi a ação de metralhadoras que determinou o fim de Virgulino Ferreira e de mais dez cangaceiros na grota de Angicos.

\section{Com Lampião, o Fim.}

O cangaço morreu com Lampião, talvez porque ele representava a última grande liderança, autêntica em suas origens, desse movimento (17).

Mas antes de Lampiã́o ser morto, o cangaço já estava sofrendo certos revezes. O próprio cangaceiro já não encontrava mais decisivas motivações para continuar naquela vida e chegou a pensar, nos derradeiros meses antes de sua morte, conforme afiança a ex-cangaceira Sila, em largar tudo e viajar para o Estado do Mato Grosso. Alguns remanescentes do movimento afirmam hoje que Lampião mostrara-se muitas vezes apático e testemunharam expressões de descontentamento que terminavam com frases como estas:

"Vô deixá uns quilo de ouro pra agaranti o futuro de minha fia e vou me danar por êsse mundo afora".

(16). - Os remanescentes do cangaço recusam-se, sistematicamente, até hoje, a indicar os verdadeiros homens que forneciam as armas para o cangaço. "Nós num cospe em prato que comeu" - afirmou "Zé Sereno", para justificar seu silêncio em relação ao problema. Sabe-se, contudo, que existiam vários fornecedores, alguns fazendeiros, e certos oficiais residentes em Sergipe.

(17). - Há uma diferença, como já foi visto, entre a primeira fase do cangaço e a segunda. $\mathrm{Na}$ primeira fase, o indivíduo ultrajado deveria vingar-se e isto aconteceu com Lampião, que depois se torna chefe do movimento. Os rapazes que se salvaram após o cerco de Angicos, procuraram logo se entregar, uma vez que lhes fora prometida anistia pelo Presidente Getúlio Vargas. 
A verdade é que, no dia da morte de Lampião, na grota de Angicos, foi encontrado no seu bornal perto de onze quilos de ouro.

As circunstâncias em que ele foi morto levam-nos a acreditar que agiu com displiscência. "Zé Sereno" afirma que o convidou várias vezes a sair "daquele buraco", verdadeira armadilha contra sua segurança. "Corisco", conforme depoimento de "Dadá", tambem não concordava com a permanência do grupo em Angicos.

"Lampião passou por milhares de coisas piores e num morreu. A volante que matou Lampião não era valente. Ele morreu porque naquele dia era capaz de morrer até de uma queda, de um espirro. No lugar que ele estava só tinha entrada, não tinha saida, porque na única saida tava os macacos. Mesmo assim vinte e três cangaceiros inda conseguiram escapar sem morrer nessa brecha. Agora qui o capitão foi teimoso naquele dia, foi mesmo. Aquelo num era lugar prá ficá" (18).

"Angicos é um pequeno afluente do rio São Francisco. Forma em certo trecho de uma de suas margens, depois de uma subida penosa e arriscada, uma gruta estocada de pedras e rodeada de alastrados de chique-chique (sic)".

"Escancara-se a gruta, como uma gargante, para acolher o visitante e o retém prisioneiro entre as suas paredes com uma única saida".

"O destino governa os vivos, pois só a força da fatalidade justifica a teimosia de Lampião em consentir ser engulido pela farna de Angicos, uma bastilha que a natureza construiu cavada entre as pedras e sem nenhuma condição estratégica para os que nela fossem encurralados".

"Mas todos ali eram seus amigos - dizia êle".

"E o estrategista de tantas façanhas no coração árido das caatingas, o guerrilheiro insuperavel na movimentação dos seus homens através dos sertões confundindo e endoidecendo as forças do governo, tinha de morrer em Angicos como um cangaceiro novato imprudente e simplório!"

"Quem conhecia a tática de Lampião, a sua eterna desconfiança, o instinto adivinhatório que o fazia arribar, de sopetão, dos coitos, quando as volantes sorrateiramente se aproximavam, ainda hoje queda-se intrigado, dada a facilidade com que se deixou ficar em Angicos, desprevinido, quase indefeso na sua displiscência, e no seu abandono!"

(18). - Depoimento de Sérgia da Silva Chagas - "Dadá". 


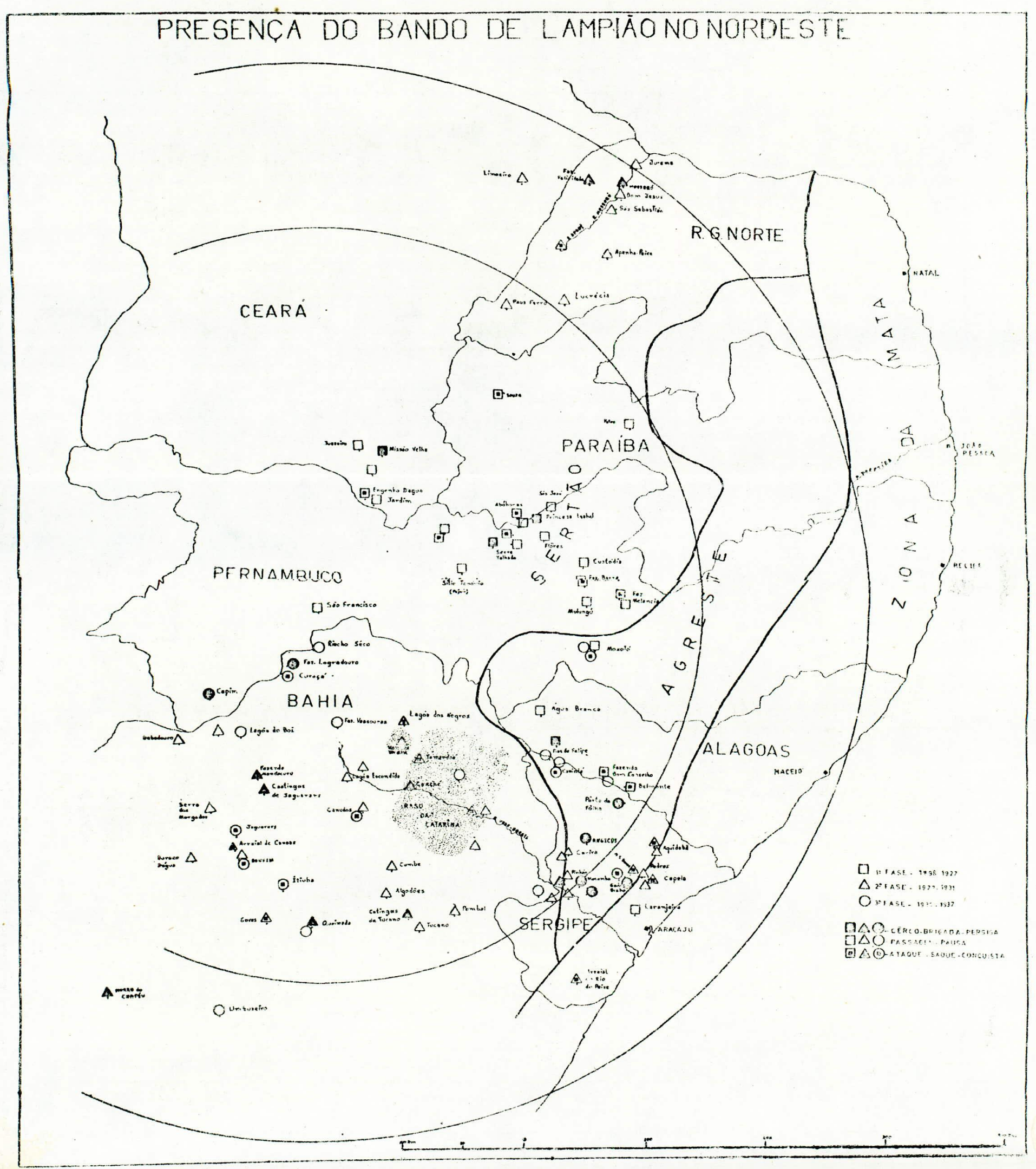


"Debalde foram as advertências de Corisco e Angelo Roque, na tarde de 27 de julho de 1938, ao se despedirem dele para dormir em outro esconderijo mais seguro".

- "Isșo aqui não merece confiança - diziam eles.

$E$ às cinco horas da manhã, ouvindo o tiroteio tiveram estas palavras:

- Aquilo é Lampiầo qui tá se ardeno, quera Deus qui desta vez escape! (19).

O mito que rodeava a pessoa de Lampião de ter o "corpo fechado" pela força milagrosa das rezas fortes, das medalhas bentas pelo padre Cícero do Joazeiro, dos "breves" e outras crendices nascidos do beatismo sertanejo, o definiam na lenda popular como um homem invulneravel em quem as balas batiam, e, inofensivas, caiain no chão" (20).

\section{- E qual o comportamento dos sobreviventes?}

"Balão" que estava no local afirma hoje:

- Foi horrivel. Ninguém quiria aceitá a morti du capitão.

Arguém chegou e falou assim - "Ele morreu mesmo". Aí foi um disispero danado. As muié choramingava, os home fazia cara forte pro mode de num chorá, tambem, mas paricia qui o mundo tinha si acabado prá todos nós. Paricia que era o fim, nós acreditava qui era. Ninguem tinha mais disposição pro modo de num fazê nada. Incostemo perto dum pé de pau e fomo curtir nosso desgosto e fazê nossas oração prá alma do finado. Agora num adiantava mais. O home já tinha ido e nós percisava ver o qui era de nós daí prá frente (21).

"Ali em Angicos, terminaria como de fato terminou a história de vinte anos de crimes do famoso cégo pernambucano que du-

(19). - O autor deve ter confundido os fatos, uma vez que "Corisco", na tarde do dia 27 do mesmo mês, tentou conseguir uma canoa para atravessar o rio São Francisco, e se encontrar com Lampião em Angicos. Scube que não havia nenhum barco; todos tinham sido utilizados por colantes para atravessar o rio, e chegar rumo a Angicos.

Pela manhã, ouviu tiros que derunciavam mais um cerco em que caiam os cangaceiros.

Mas, quando o fogo cessou, depois de apenas 40 minutos, esperou notícias; soube da morte do chefe Lampião; não pensou mais em atravessar. Esperou alguns dias, pois tinha certeza de que a região estava cheia de vol rrtes. Só depois corseguiu levar a cabo a vingança planejada (depoime to de Sérgia da Silva Chagas, vulgo "Dadá") .

(20). - Goes (Joaquim), op. cit., págs. 231-232.

(21). - Depoimento de Guilherme Alves, vulgo "Balão". 
rante dez anos enlutou o Ceará, Rio Grande do Norte, Paraíba, Pernambuco, Alagoas e em outros dez anos lavou de sangue Bahia e Sergipe".

"Para um bandido do porte de Lampião a sua morte foi vulgar, o seu fim sem os lances emocionantes que era de se esperar, foi um fim banal. Um assassinato a traição e nada mais".

"Se o tivessem abatido de armas nas mãos numa luta aberta em dois campos leais, se o tivessem pegado num combate igual, hoje o capítulo dessa história talvez fosse escrito de modo diferente".

"Mas a traição the negou o direito de morrer brigando, de morrer falando pela boca do seu mosquetão, de morrer como viveu, de armas nas mãos e dedo no gatilho" (22).

Corisco tentou apanhar o bastão, empunhar a nova liderança do cangaço, 'mas lhe faltaram as condições inatas que sobraram sempre em Lampião.

Com a morte do chefe cangaceiro, o movimento perde sua força, a força de um lider que apesar de cansado e querendo deixar a Luta, continuou, talvez por sentir a impossibilidade de se refugiar em algum lugar de qualquer Estado.

Seus companheiros permaneceram a seu lado, até o momento em que o chefe, não mais existindo, sem uma razão forte para continuar (vingança) e sabendo da anistia decretada pelo presidente aos remanecentes do movimento, deixaram a luta e o cangaço morreu.

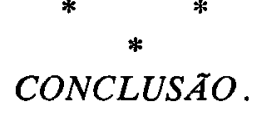

O poder econômico representa, portanto, na estrutura estatal, um valor que deve ser levado em consideração. Pela força econômica, o coronel se vai impor como força política, isto porque, alicerçado em bases econômicas produtivas, de bens exportáveis, ele se vai firmando junto ao Estado que precisa dele, seja ele quem for, não importando o tipo de caudilho, contanto que domine a área para o Estado, para o qual é importante esse domínio, porque o poder econômico é fonte de renda. Nas crises econômicas eles recebem ajuda do Poder Público, como recompensa pela legião de eleitores sempre a eles subordinada. Esses eleitores são o escudo do coronel no seu relacionamento com a situação. O Coronel, dono de terra e de outros bens de produção, vai controlar o povo que vive na região.

(22). - Goes (Joaquim), obr. cit., págs. 234. 
O Estado foi paternalista desde o tempo da Coroa, que necessitava dos senhores de terra, que representavam fonte de renda para a metrópole.

O Estado sempre lhe delega poderes, e o Coronel fica vinculado pelos bens materiais.

Temendo a ruptura do seu poder, e a consequente subida de um concorrente político - outro coronel - manda seus filhos ou protegidos estudar em Faculdades de Direito, para que se tornem futuros defensores de seus interesses, tanto na Câmara Municipal como na Assembléia Legislativa. E a época dos bachareis.

A fragmentação das terras, e a consequente concentração da propriedade fundiária, determinaram as lutas de grupos no Nordeste.

O Coronel, baseado na estrutura econômico-social, era violento, e usava a violência porque do seu lado estava a força do Estado, e ninguem se atreveria a enfrenta-lo; não sofreria represálias.

Somente os cangaceiros, homens que representavam no sertão a bravura pessoal e ofensiva, rebelaram-se contra as violências do coronelismo.

\section{ANEXO 1.}

Considerando que o fenômeno do cangaço ainda tem representantes vivos, foi possivel realizarmos uma pesquisa empírica. Os dados foram coletados em seis estados: Paraíba, Pernambuco, Bahia, Sergipe, Alagoas e Ceará.

O critério da seleção da amostra, bastante simples e limitado, não levou em consideração a proporção do seu universo.

E um estudo que visa a compreender o que tinha maior relação com o assunto e, por isso, era necessário que fossem entrevistados sertanejos com mais de 60 anos, de preferência, relacionados com os cangaceiros e que tivessem vivido na área de influência do cangaço. Dai o estudo feito em dois níveis: num deles, para coletar dados, realizamos entrevistas, ouvidas e gravadas pessoalmente. Num segundo momento, utilizamos a técnica de questionários, submetidos a 68 pessoas.

O questionário tem duas partes: a primeira visa a mostrar o aspecto econômico e social da área, a solidariedade e anomia.

A segunda parte tem como objetivo conhecer os reais motivos da entrada e permanência no movimento. E apresentada em dois aspectos: 


\section{MOTIVO DA ENTRADA NO CANGAÇO}

Porcentagem amostra: 67 casos

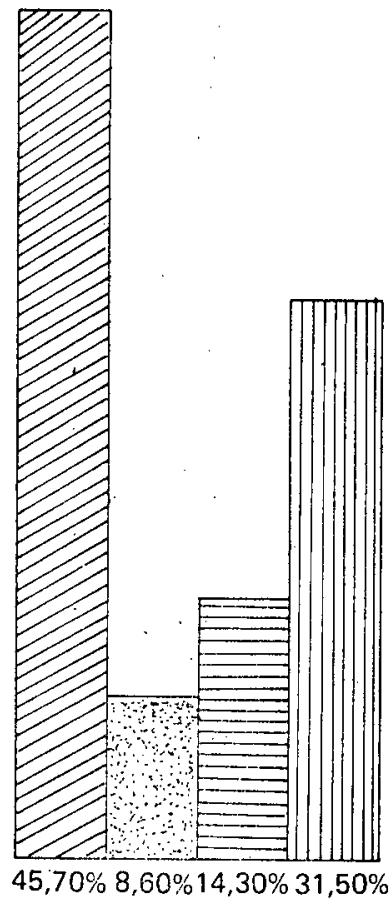

Perseguido

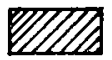

Voluntário

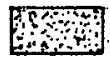

Influenciado

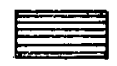

Vingança

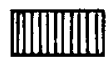




\section{DISTRIBUIÇÃO PORCENTUAL SEGUNDO O TIPO DE OCUPAÇĀO}

\section{Amostra 67}

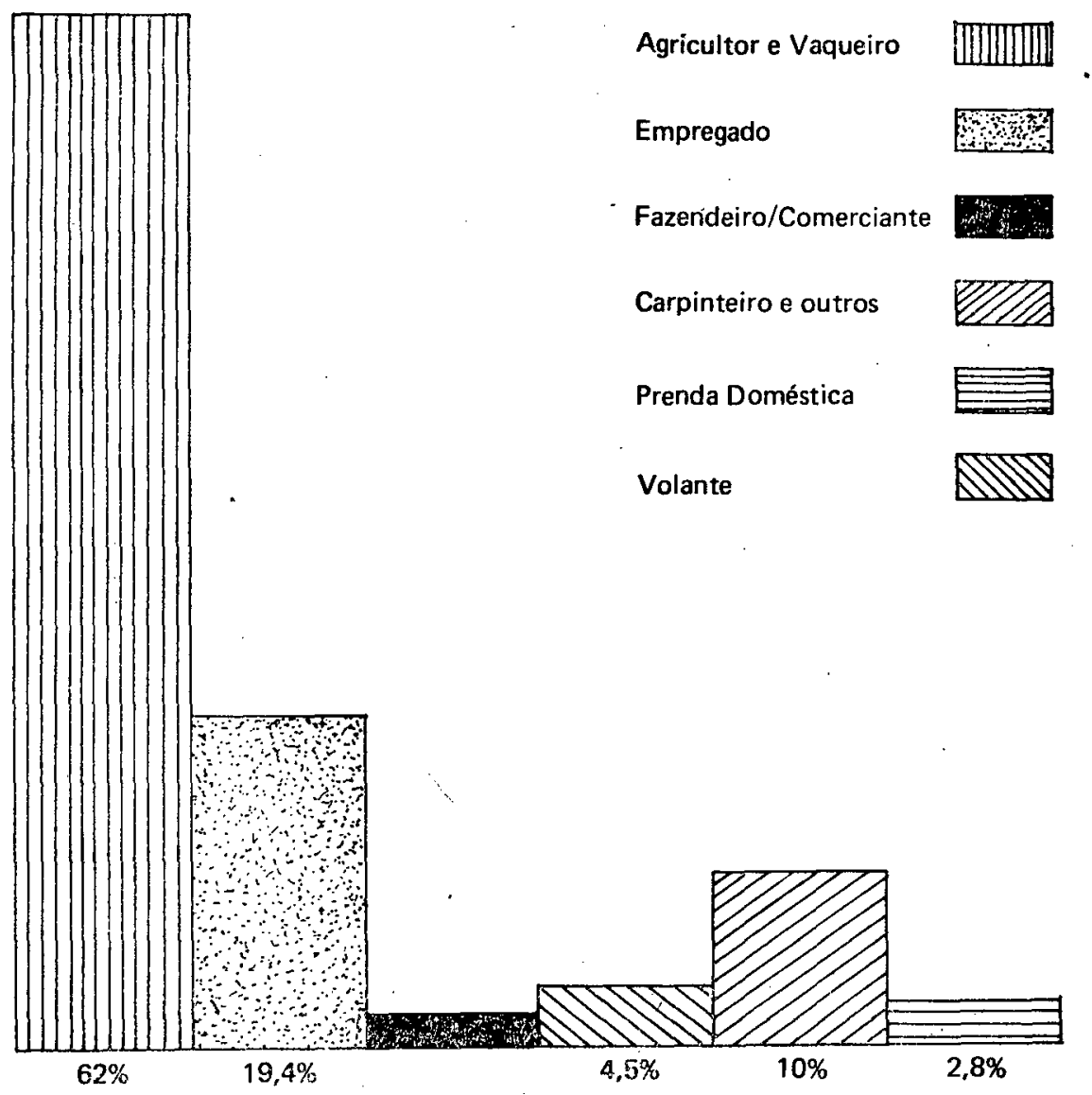




\section{REFERÉNCIA SOBRE FOME NA ÉPOCA DA SECA}

Total da amostra 67 - porcentagem

Coronéis passaram fome

Ninguém passou fome

Várias famílias passaram fome

Todo o povo jassou fome
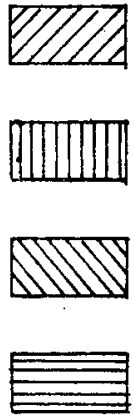

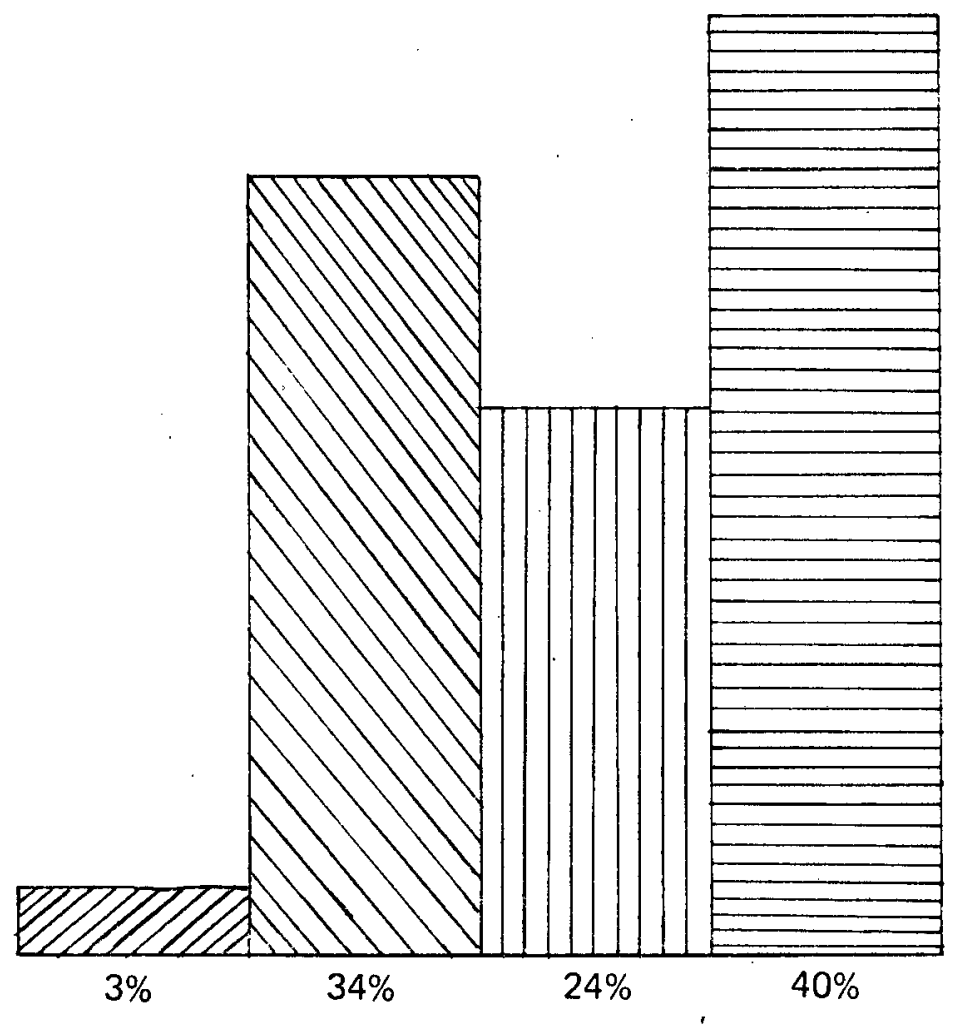




\section{PERCENTAGEM SOBRE AS PESSOAS QUE FORAM OU NĀO DESPEDIDAS PELOS CORONËIS NA ÉPOCA DA SECA}

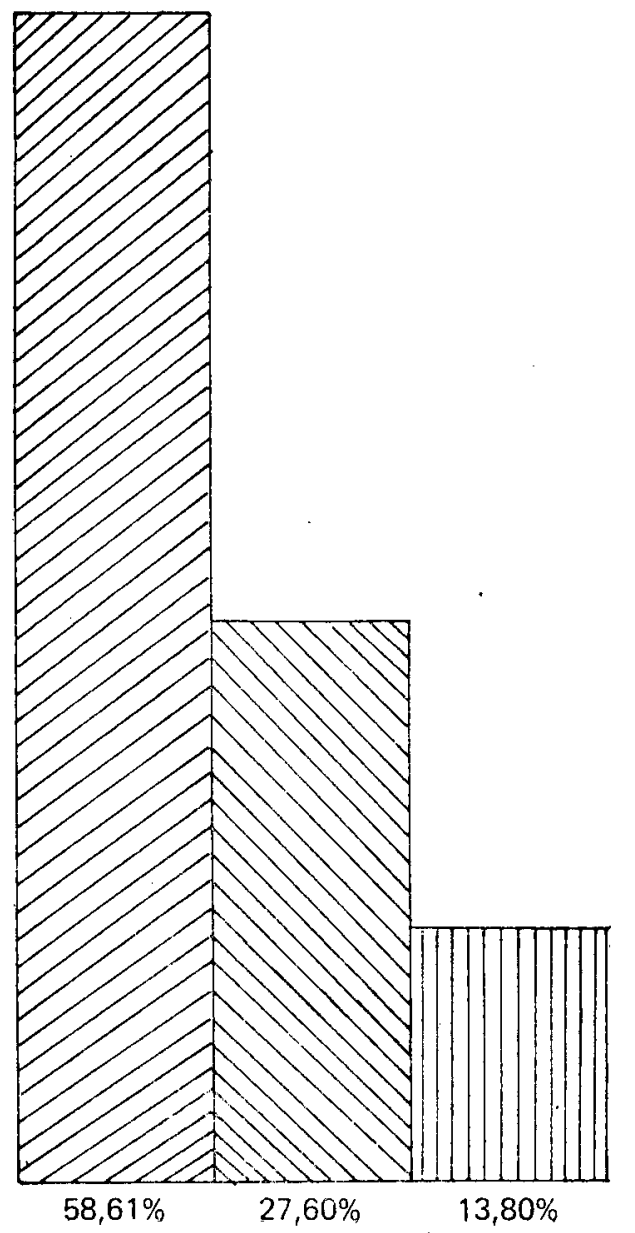

Coronéis que não despediram seus empregados

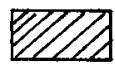

Coronéis que despediram seus empregados

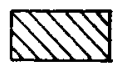

Pessoas que não responderam [.].].].]. 


\section{DISTRIBUIÇĀO PERCENTUAL SEGUNDO O TIPO DE OCUPAÇĀO Amostra 67}

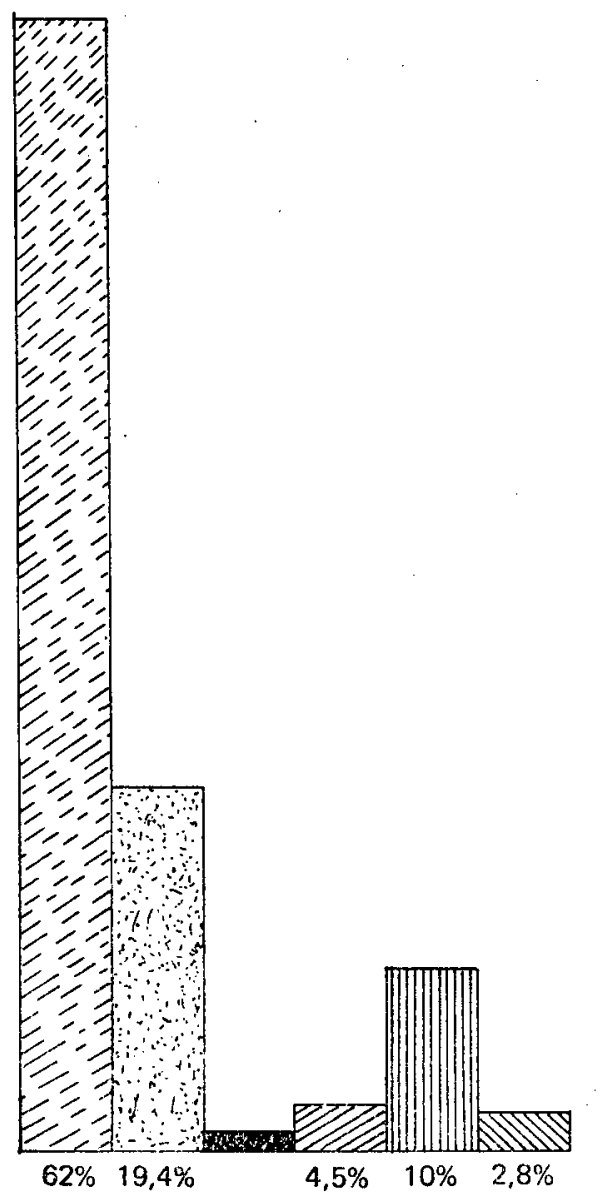

Agricultor e Vaqueiro

Empregado

Fazendeiro e Comerciante

Volante

Carpinteiro e Outros

Prendas Domésticas

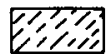
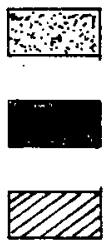

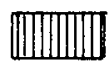

जाIIIV 
RELAÇÃo ENTRE TRABALHO E POSSE DE ROçAS TOTAL DA AMOSTRA - 67 - PERCENTAGEM

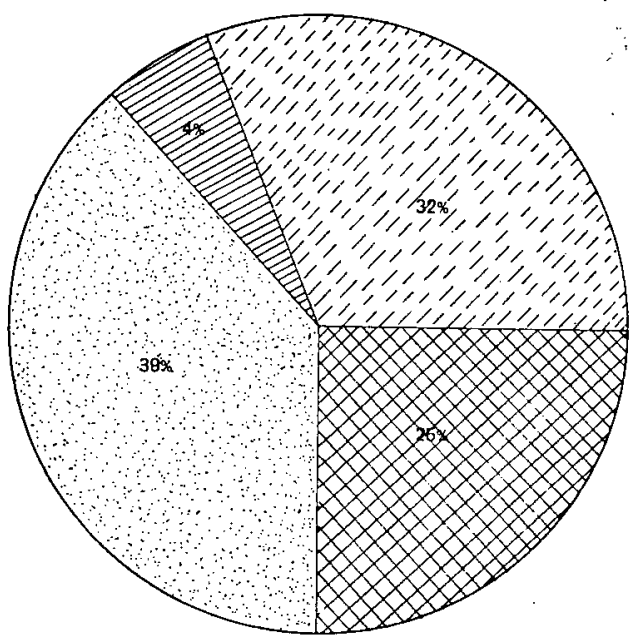

Empregados e tinham roca

Empregados e não tinham roça

Nāo eram empregados e nāo tinham roça

Nöo eram empregados e tinham rọ: 
$-170-$

SUJEITO A QUEM SE PEdIU AJUdA DURANTE A SECA

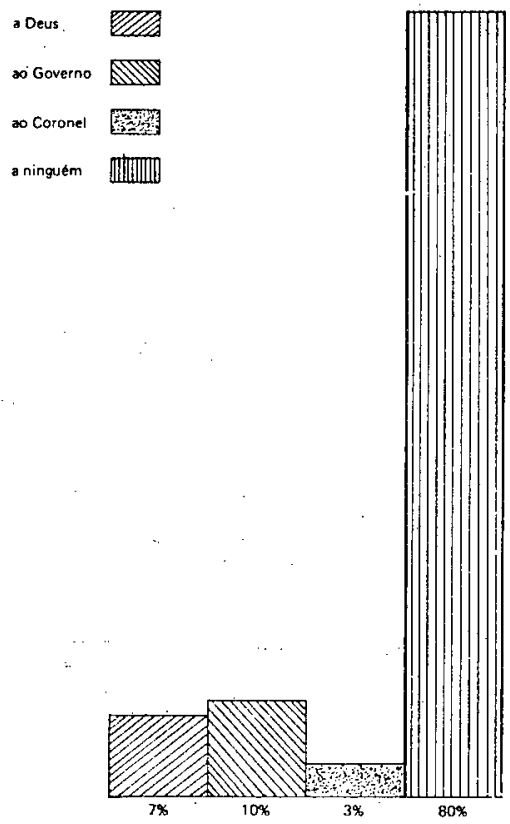


Uma parte para os ex-integrantes dos grupos de cangaceiros e outro grupo de itens para pessoas muito relacionadas com um cangaceiro que pudessem falar com precisão sobre sua vida.

Os dados empíricos foram submetidos ao teste estatístico. Não usamos dados quantitativos, pois, não seria possivel apresentar provas em termos de números, estabelecendo comparações muito gerais com a realidade. Usamos apenas números para provar, qualitativamente, o que demonstramos no decorrer do trabalho. Por isso utilizamos porcentagens, médias, proporções e relações de variáveis qualitativas $\left(\mathrm{x}^{2}\right)$.

Em função da hipótese, realizámos uma pesquisa no sertão do Nordeste, aplicando questionário, cujo universo é constituido de pessoas ligadas, direta ou indiretamente, ao fenômeno do cangaço.

A pesquisa buscou dados que ainda existem, procurando provar qualitativamente a hipótese levantada. Os dados são:

a). - Mais indicativos que conclusivos.

b). - Faixa numericamente limitada.

c). - Pesquisa limitada no tempo, porque não se pode provar que o período por nós analisado seja o mais representativo do cangaço.

d). - Os dados se relacionam com uma parcela da população envolda no fenômeno; alem disso, pessoas distanciadas no tempo.

e). - $\mathrm{O}$ que apresentamos nesse item representa amostra significativa, dentro das possibilidades existentes.

Os elementos dos questionários analisados, vão permitir uma caracteriżação de orientação, não se pretendendo chegar a um resultado conclusivo. Utilizamos os seguintes critérios por nós estabelecidos:

Número de filhos do inquirido no questionário; nivel de instrução; trabalho - em dois sentidos: qualidade do trabalho, ter ou não trabalho remunerado, mais ou menos estavel.

Utilizamos essas variáveis unidas, porque, assim, o resultante nos dá uma noção do que era o sertanejo, em seus aspectos gerais. Baseados nesses critérios, escolhemos dois grupos: social e econômico.

Dentro da nossa análise, consideramos, do primeiro grupo, o de nivel social e econômico baixos: 


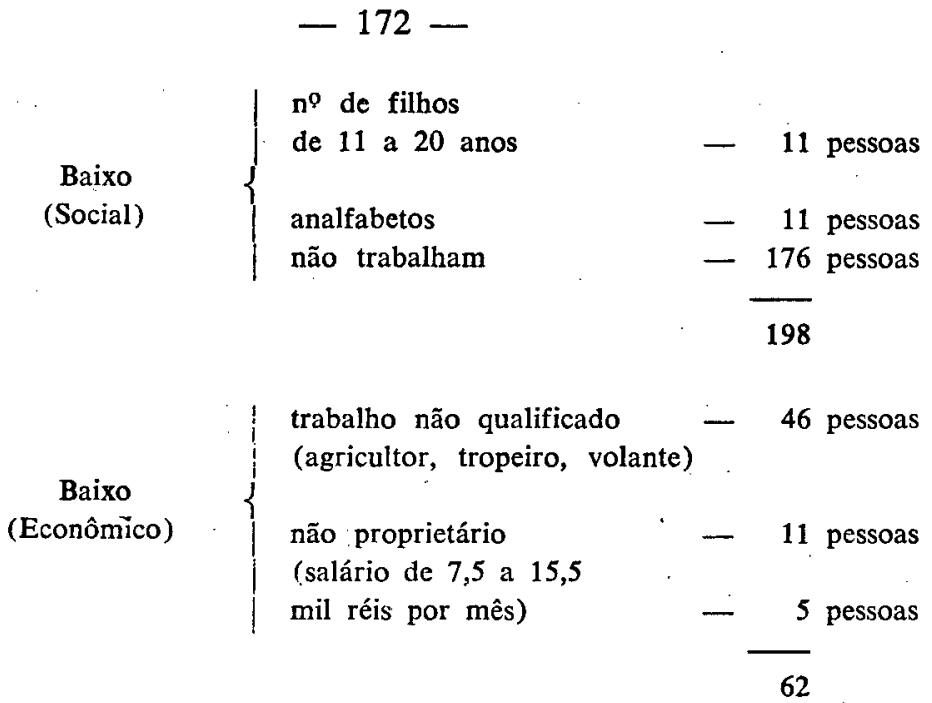

E do segundo grupo, níveis social e econômico altos:

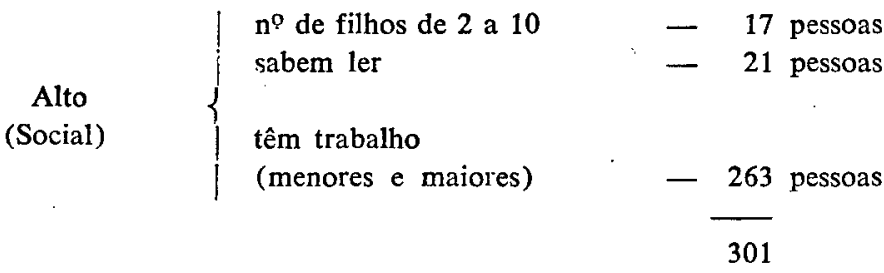
Alto
(Econômico)
proprietários
salário de 22,5 a $50 \mathrm{mil}$
réis ou mais por mês

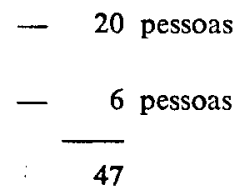

Os dados acima indicam a existência de dois níveis, chegando-se à conclusão de que estão, dentro do nivel superior social e econômico, 348 indivíduos.

Com nivel social superior e nivel econômico inferior, 363 indivíduos. 
Nivel econômico alto e social baixo, 245 individuos. No nivel econômico e social baixo, estão 260 elementos.

Residiu, a preocupação do investigador, em ver se existe relação entre o nivel Econômico e Social; utilizando as provas estatísticas $\left(\mathrm{x}_{2}\right)$, chegou-se à conclusão de que esses dois níveis têm relação, isto é, existem dois grupos com diferenças sócio-econômicas entre eles, mas que se correspondem entre os indivíduos de cada grupo.

Dai concluirmos que, para o sertanejo ter um comportamento de revolta, os dois aspectos analisados, sócio-econômico è o sócio cultural, em outro nivel (sem cruzamento de variáveis), levaram o sertanejo a ser cangaceiro.

Unindo-se o alto social e econômico, verificamos que, dentro do quadro de nivel social, o grupo alto corresponde às pessoas alfabetizadas, com trabalho fixo e com pequeno número de filhos; sob o ponto-de-vista econômico representa os proprietários de terra, comerciantes e artesãos com salários superiores à média geral.

O grupo baixo socialmente representa os analfabetos, com o número de filhos superior a 10 e sem trabalho fixo. Economicamente pertencem ao quadro de trabalhadores não qualificados, sem qualquer propriedade, recebendo salário inferior a $15,5 \mathrm{mil}$ réis por mês.

$\mathrm{Na}$ época analisada, desses dois grupos podem surgir os cangaceiros, porque os motivos que afetaram a sua conduta tinham a mesma e grande importância para os de nivel econômico e social alto e para o grupo baixo.

A questão da honra, por exemplo, afetava ambos os grupos. Os padrões culturais são mais ou menos equivalentes a todos os elementos da comunidade, porque as normas, valores, tradições e costumes, correspondem a seus membros, indistintamente.

As razões mediatas do cangaço são de ordem social e econômica e a razão imediata é a vingança, motivo forte para levar o sertanejo a romper com sua vida pacata.

Independentemente da vingança, existiram outros fatores que levaram, o sertanejo a se transformar em cangaceiro.

O questionário por nós elaborado visou a abordar três tipos de indivíduos, relacionamos com o fenômeno do cangaço: 
a). - sertanejos, do sexo masculino, com mais de 60 anos, que moravam na área por onde passaram os revoltados e em áreas onde sertanejos se transformaram em cangaceiros.

b). - indivíduos intimamente ligados aos cangaceiros, conhecendo profundamente sua vida.

c). - ex-cangaceiros.

O total de questionários respondidos foi apenas 68 , mas seu valor é qualitativo.

Esses dois últimos tipos de indivíduos, que responderam ao questionário, é qque estabeleceram os motivos pelos quais o sertanejo se transformava em cangaceiro.

$\begin{array}{rrl}16 & 45,7 \% & \text { perseguidos } \\ 3 & 8,6 \% & \text { voluntários } \\ 5 & 14,2 \% & \text { influenciados } \\ 11 & 31,5 \% & \text { vingança. }\end{array}$

As causas de vingança que representam os $31,5 \%$ dos sertanejos que ingressaram no cangaço são:

a). - roubo de terra.

b). - violência sexual.

c). - assassínio de parentes.

d). - abusos do poder.

Os motivos que levaram à perseguição do sertanejo e que provocaram seu ingresso no cangaço conforme $45,7 \%$ dos entrevistados no questionário foram:
a). - parentesco com cangaceiro.
b). - coiteiro.
c). - perseguido pela justiça.
d). - jagunço de coronel perseguido.
e). - sertanejo perseguido pela volante (1).

(1) - Observação: - Existem ainda os influenciados. No nosso questionário aparecem, em pequena quantidade, os voluntários. Consideramo-los, assim, apenas para obedecer rigorosamente às suas respostas, muito embora eles estivessem perfeitamente enquadrados dentro do percentual dos influenciados. 